\title{
Immunological Aspects of Reticulum Cell Neoplasia
}

\author{
A. E. STUART, ${ }^{*}$ PH.D., M.B., M.R.C.P.
}

Hodgkin's disease occupies a place of central importance in the spectrum of reticulum cell neoplasms. Its outstanding histological feature is the diversity of cell type, a diversity shown by no other tumour. The usual explanation for this phenomenon is that a primitive but malignant reticulum cell gives rise to myeloid, lymphoid, and fibroblastic elements. Not all have believed this improbable developmental sequence, and I shall now summarize the histological evidence for the suggestion that the cellular infiltrate is a host reaction.

\section{Host Reaction}

There are six main histological features suggestive of host reaction.

Firstly, eosinophilia ${ }^{1}$ whose association with hypersensitivity is well known; nevertheless, patients with Hodgkin's disease are anergic, so what are the eosinophil leucocytes doing?

Secondly, necrosis frequently has a curious serpiginous pattern, unlike the central necrosis so often seen in other neoplasms. Is this a reflection of virus cytotoxicity or even a manifestation of local hypersensitivity?2 Thirdly, amyloidosis is a complication of prolonged immunization and is found in myeloma, where high levels of serum globulin are found. Amyloid may occur in Hodgkin's disease in the follicular area of the lymph node and the malpighian bodies of the spleen. Fourthly, fibroblast proliferation is sometimes very pronounced. Nevertheless, the cells enclosed by the fibrous tissue may be either small lymphocytes or mainly large reticulum cells, and I doubt if the degree of fibroblastic proliferation can be construed as an effective measure of host defence.

Fifthly, erythrophagocytosis and the resulting deposition of haemosiderin are sometimes seen. Clearly the recognition system of the macrophages has failed or the erythrocytes themselves have undergone a modification which renders them foreign to the host.

Lastly, plasma cells are found in variable numbers, both in reticulum cell sarcoma and Hodgkin's disease, and this is at least consistent with a reactive process.

\section{Anergy}

The susceptibility of patients with Hodgkin's disease to infection has long directed attention to an immunological deficiency in these conditions. The tuberculin test is often negative in this condition, even in the presence of active tuberculosis, and so are the reactions to various other microbial allergens such as Candida albicans and Trichophyton gypseum. ${ }^{34}$ Nevertheless, a particular patient may fail to react because he is anergic or because he has never been exposed to the particular allergen. Using dinitrochlorobenzene (DNCB) Aisenberg found that this sensitizes more than $90 \%$ of normal people, reflecting the integrity of the cell mediated immune mechanism. On the other hand, all the 25 patients with active Hodgkin's disease were anergic, while 14 out of 15 with inactive disease were hyperergic. The reason for the association of Hodgkin's disease with anergy is not clear, but the latter is known to occur in conditions in which the macrophage system of cells is primarily disturbed, such as leprosy and sarcoidosis. ${ }^{5}$.

The concept of an immunological deficiency in Hodgkin's disease has been supported by Kelly et al., who reported a delay in the rejection of a homograft in this disorder. ${ }^{6}$ Smithers has also reported the persistence of a skin homograft in a patient with Hodgkin's disease. ${ }^{7}$ Thus at the present time the evidence for a profound defect in cellmediated immunity is overwhelming.

* Reader in Pathology, University of Edinburgh

\section{Circulating Lymphoid Cells}

The lymphoid cell population in Hodgkin's disease differs from normal blood in three ways. ${ }^{8}$ Firstly, there are more large lymphoid cells actively secreting DNA; secondly, there are more medium-sized cells with basophilic cytoplasm; and, thirdly, occasional plasma cells are seen. Crowther et al. ${ }^{8}$ suggested that these changes were consistent with a process of immunization, though "it is not clear against what antigen it is directed." They feel that this response might be against a tumour-specific antigen but also mention an analogy to the experimental condition of graft-versus-host disease.

Normal lymphocytes respond in vitro to phytohaemagglutinin $^{9}$ and undergo transformation into primitive-like cells, which is detected by an increased uptake of radio-labelled thymidine. The degree of transformation corresponds well to cell-mediated immunity. Lymphocyte transformation is depressed in Hodgkin's disease, even in its early stages. ${ }^{10} 11$ Another property of the lymphocyte is its ability to destroy fibroblasts and Thomas et al. have found that this is diminished in Hodgkin's disease. ${ }^{12} 13$ Clearly the lymphocytes, though morphologically normal, are abnormal in their in-vitro responses.

\section{Immunoglobulins}

Antibody formation is well preserved in Hodgkin's disease, ${ }^{14}$ though possibly there is a difference in response to primary and secondary immunization. The serum immunoglobulin levels have failed to show any systematic abnormality. Irunberry and Colonna found a rise in $\mathrm{IgG}$ in $32 \%$, in $\operatorname{IgA}$ in $19 \%$, and $\operatorname{IgM}$ in $14 \% .{ }^{15} \mathrm{My}$ own small series showed that in reticulum cell sarcoma there was an irregular but definite rise in immunoglobulin levels. All immunoglobulins were affected-that is, polyclonal gammopathy, a quite distinct picture from the so-called monoclonal gammopathies found in neoplastic immunoglobulin-secreting disorders such as myeloma or Walderström's disease. ${ }^{16-22}$

\section{Reed-Sternberg and Reticulum Cells}

In a recent cell culture study of human lymph node, spleen, thymus, tonsil, and lung, Miss Davidson and I have isolated a large branching cell. ${ }^{23-25}$ Is this the reticulum cell? Until we know more about reticulum cells, Hodgkin's disease will remain a condition in search of a definition. The ReedSternberg cell is clearly an alien; but to what extent are the other mononuclear cells and lymphocytes seen in Hodgkin's disease also an intrinsic part of the neoplastic process? This distinction is surely important in treatment where the neoplastic elements ought to be suppressed and the reactive ones augmented and strengthened.

Is the Reed-Sternberg cell a target against which is focused the armament of cellular immunity or is it an aggressor cell capable of reacting immunologically with host antigens?

Kaplan and Smithers first made the stimulating suggestion that graft-versus-host disease shared certain features with Hodgkin's disease. ${ }^{26}$ Recently Smithers said: "The similarities of these immunological disorders to Hodgkin's disease with its frequent loss of weight, progressive lymphoid depletion and anergy appeared clear. The supposition that some of the tumour cells in Hodgkin's disease might become changed through irregular growth and so act as though they were foreign, producing a GVH which would account for the previously unexplained manifestations seemed 
reasonable." Grifoni et al. suggest that two lymphocyte populations are in conflict ${ }^{27}$ and mention that their observations support the view of Hamilton Fairley that "lymphocytes may be committed to react against Hodgkin's tissue." 28 This theme of autoaggressive activity recurs in the literature on Hodgkin's disease..$^{29} 30$

\section{Graft-versus-host Disease}

In a series of experiments graft-versus-host disease was induced in adult mice by injecting parental lymphoid cells into the first generation hybrids. The injected cells colonized the spleen and lymph nodes, and mounted an immunological attack on host tissues. Even in the early stages of the disease, striking histological changes have occurred. Widespread infiltration by lymphoid cells in many organs was seen-liver, pancreas, adrenal, and maxillary glands, and even muscle. Atrophy of the intestine occurred early and is probably important in the wasting syndrome. When we contrast the main features of graftversus-host disease with Hodgkin's disease there are certain features in common (see Table).

Comparison of Hodgkin's Disease and Graft-versus-host Disease

\begin{tabular}{|c|c|c|}
\hline & Disease & Features \\
\hline \multirow{2}{*}{ Similarities } & Hodgkin's Disease & $\begin{array}{l}\text { Invasive nature of growth } \\
\text { Occasional presence of splenic amyloid } \\
\text { Wasting } \\
\text { Depletion of lymphocytes in terminal state }\end{array}$ \\
\hline & $\begin{array}{l}\text { Graft-versus-host } \\
\text { Disease }\end{array}$ & $\begin{array}{l}\text { Invasion of multiple organs by small } \\
\text { round cells } \\
\text { Presence of splenic amyloid } \\
\text { Wasting } \\
\text { Depletion of lymphocyte in terminal state }\end{array}$ \\
\hline \multirow{2}{*}{ Differences } & Hodgkin's Disease & $\begin{array}{l}\text { Large masses at necropsy } \\
\text { Reticulum cells and Reed-Sternberg cells } \\
\text { Necrosis common } \\
\text { Eosinophils common } \\
\text { Gut changes uncommon, exception } \\
\text { primary form }\end{array}$ \\
\hline & $\begin{array}{l}\text { Graft-versus-host } \\
\text { Disease }\end{array}$ & $\begin{array}{l}\text { No large masses at necropsy } \\
\text { Pyronophilic mononuclear cells and } \\
\text { histiocytic proliferation } \\
\text { Necriss rare } \\
\text { Eosinophils rare } \\
\text { Gut changes common }\end{array}$ \\
\hline
\end{tabular}

Dr. Regunathan and I have investigated the function of macrophages in animals suffering from early graft-versus-host disease.

Firstly, the macrophages are bigger and more pleomorphic than normal with an increased affinity for particular matter. Secondly, they no longer discriminate between self and not-self, surely reflecting a fundamental change in behaviour. When macrophages from normal animals are mixed with lymphocytes from normal animals of the same strain, little or no interaction occurs-that is, there is no adherence or death of cells. On the other hand, when macrophages from animals with graft-versus-host disease are used, their interaction with lymphocytes results in the death of the cella singularly unphysiological state of affairs. Furthermore, the serum of animals with this disease contains a factor, presumably antibody, which promotes adherence of lymphocytes to macrophages. This antibody reduces the severity of the cellmediated necrotizing reaction, presumably by coating the cell with a layer of protective protein.

Perhaps these cell-culture techniques can be applied to the study of the cellular pathology in reticulum cell neoplasia and to the problem of autoaggression amidst the turbulent cell population of Hodgkin's disease.

I am indebted to Dr. J. Habeshaw and Dr. P. Regunathan for their help and permission to use the data from their work.

\section{REFERENCES}

1 Symmers, D., fournal of the American Medical Association, 1945, 128, 1248.

2 Sirtori, C., Lancet, 1970, 1, 92.

3 Aisenberg, A. C., Fournal of Clinical Investigation, 1962, 41, 1964.

- Aisenberg, A. C., Cancer Research, 1966, 26, 1152.

5 Chase, M. W., Cancer Research, 1966, 26, 1097

- Kelly, W. D., Lamb, D. L., Varco, R. L., Good, R. A., Annals of the New York Academy of Sciences, 1960, 87, 187

? Smithers, D. W., British Medical fournal, 1967, 2, 263 and 337.

Crowther, D., Fairley, G. H., and Sewell, R. L., British Medical fournal, 1969, 2, 473.

- Eggerth, G., Kuhbock, J., and Pokorny, D., Wiener Zeitschrift für innere Medizin und ihre Grenzgebiete, 1969, 50, 314.

10 Szur, L., Harrison, C. V., Levene, G. M., and Samman, P. D., Lancet, 1970, 1, 1016.

11 Fazio, M., and Bachi, C., Nature, 1967, 215, 629.

12 Thomas, J. W., Boldt, W., and Horrocks, G., Canadian Medical Association fournal, 1968, 99, 303.

18 Havemann, K., Deutsche Medizinische Wochenschrift, 1969, 37, 1867.

14 Barr, M., and Fairley, G. H., Lancet, 1961, 1, 1305.

15 Irunberry, J., and Colonna, P., La Presse Medicale, 1970, 78, 187.

16 Blefari, D., and Gambertoglio, G., Il Cancro, 1968, 21, 529.

17 Castuma, J. C., Cicchetti, G. E. H., and Bergna, L. J., Sangre, 1967, 13, 275.

18 Ferrari, S., Foggi, C. M., and Serafini, N. A., Annali dell'Instituto Carlo Forlanini, 1968, 28, 292.

10 Goldman, J. M., and Hobbs, J. R., Immunology, 1967, 13, 421.

20 Poldipson, L., and Ponteri, J., Life Sciences, 1967, 6, 2635.

21 Pisi, E., Feliciantonio, R. D., Figus, E., and Ferri, S., Minerva Medica, 1968, 59, 944.

22 Stiehm, E. R., and Fudenberg, H. H., Pediatrics, 1966, 37, 715.

23 Stuart, A. E., Fournal of Pathology, 1970, 101, 1 .

24 Stuart, A. E., and Davidson, A. E., fournal of Pathology, 1970, 102. In press.

25 Stuart, A. E., and Davidson, A. E., fournal of Pathology, 1970, 103. In press.

${ }_{26}$ Kaplan, H. S., and Smithers, D. L., Lancet, 1959, 2, 1.

27 Grifoni, V., Del Giacco, G. S., and Tognella, S., British Medical fournal, $1969,3,414$

28 Fairley, G. H., British Medical fournal, 1969, 2, 467

29 Johnson, A. G., Radiological Clinics of North America, 1968, 6, 41.

30 Woodruff, M. F. A., Lancet, 1964, 2, 265.

\title{
Host Defence Mechanisms in Burkitt's Lymphoma and Kaposi's Sarcoma : The Clinical Evidence
}

\author{
D. P. BURKITT, ${ }^{*}$ M.D., F.R.C.S.
}

Choriocarcinoma and Burkitt's lymphoma are unique among malignant tumours in the high rate of cures that can be obtained with chemotherapy. The former is in a category of its own since it develops from fetal rather than host cells. Thus, with this exception, Burkitt's lymphoma is the only form of cancer in which a high proportion of apparent cures can be obtained with chemotherapy alone.

Two other tumours, malignant melanoma and Kaposi's sarcoma, also have a tendency to occasional spontaneous remission. I propose to discuss some aspects of Kaposi's sarcoma

\footnotetext{
* External Scientific Staff, Medical Research Council, London W.1.
}

together with Burkitt's lymphoma, having had considerable clinical experience of both these tumours.

\section{Burkitt's Lymphoma}

Characteristically Burkitt's tumour responds to a wide range of cytotoxic agents and a high proportion of patients survive apparently free from tumour. Thus there are almost $100 \%$ of long-term survivals in patients with one or more tumours limited to the face. ${ }^{1}$ Even in patients with intra-abdominal, intrathoracic, or skeletal tumours (other than face) there was a survival rate of over $50 \%$. Moreover, Williams has shown that 